$$
\begin{aligned}
& \text { برونزا }
\end{aligned}
$$

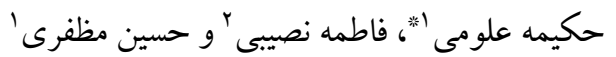

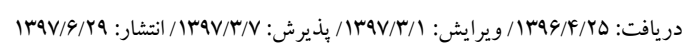

$$
\begin{aligned}
& \text { كروه اكولوزى، ئزوهشگاه علوم و تكنولوزى ييشر فته و علوم محيطى، دانشگاه تحصيلات تكميلى صنعتى و فناورى ييشرفته، كرمان، ايران }
\end{aligned}
$$

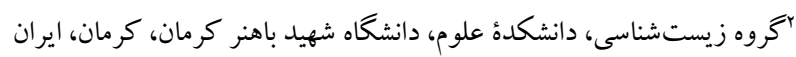

$$
\begin{aligned}
& \text { h.oloumi@kgut.ac.ir مسئول مكاتبات }
\end{aligned}
$$

קُكيده. گياهان دارويى منابع غنى از متاليتهاى ثانويه هستند. شاهى گياهى واجد تركيبات مؤثره و متابوليتهاى ثانويه ازجمله تركيبات يلىفنل، آنتوسيانين و

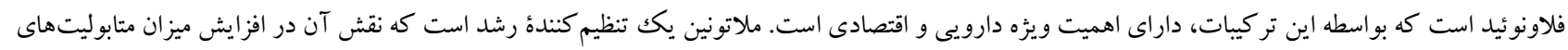

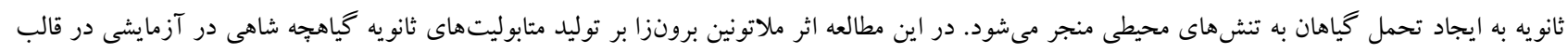

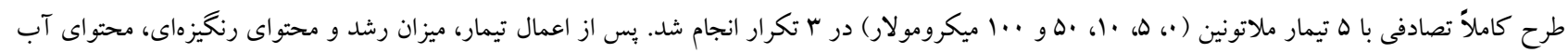

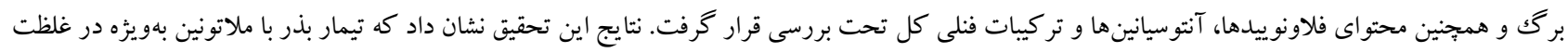

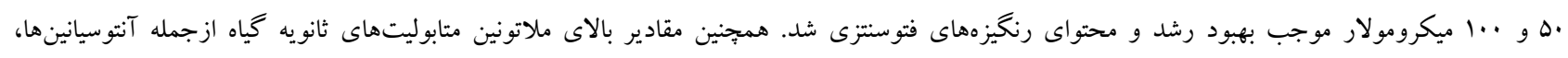

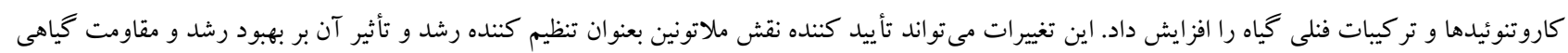

وازههاى كليدى. آنتوسيانينها، تر كيبات فنلى، فلاونوئيدها، كلروفيل، كاروتنوئيدها

\title{
Investigation of the growth rate and secondary metabolites content of Lepidium sativum under exogenous melatonin treatment
}

\author{
Hakimeh Oloumi ${ }^{1}{ }^{*}$, Fatemeh Nasibi ${ }^{2}$ \& Hossein Mozaffari ${ }^{1}$ \\ Received 16.07.2017/ Revised 22.05.2018/ Accepted 28.05.2018/ Published 20.09.2018
}

${ }^{1}$ Department of Ecology, Institute of Science and High Technology and Environmental Sciences, Graduate University of Advanced Technology, Kerman, Iran

${ }^{2}$ Department of Biology, Faculty of Science, Shahid Bahounar University of Kerman, Kerman, Iran

*Correspondent author: h.oloumi@kgut.ac.ir

\begin{abstract}
Medicinal plants are rich sources of secondary metabolites. Lepidium sativum possesses active compounds and secondary metabolites, including polyphenol, anthocyanin and flavonoid compounds, which have special pharmaceutical and economic importance. Melatonin, as a bio-stimulator compound, has a regulatory role on the amount of secondary metabolites and plant tolerance facing environmental stresses. In this study, the effect of exogenous melatonin on secondary metabolites production on Lepidium sativum was investigated in a completely randomized design with five melatonin treatments $(0,5,10,50$ and $100 \mu \mathrm{M})$ in 3 replications. After applying each treatment, the growth rate and the content of the photosynthetic pigments, the leaf water content as well as the content of flavonoids, anthocyanins and total phenolic compounds investigated. The results indicated that seeds treated with melatonin, especially at concentrations of 50 and $100 \mu \mathrm{M}$, showed improvement in the growth parameters and the content of photosynthetic pigments. High levels of melatonin also increased the plant's secondary metabolites, including anthocyanins, carotenoids and plant phenolic compounds. These effects confirm the role of melatonin as a growth regulator and its impact on plant growth and resistance.
\end{abstract}

Keywords. anthocyanins, carotenoids, chlorophyll, flavonoids, phenolic compounds 
Bajwa et al., 2014). ملاتونين ريشهزايى را از طريق القاى اكسين و توليد اندام هوايى را از طريق افزايش سيتو كينين تنظيم

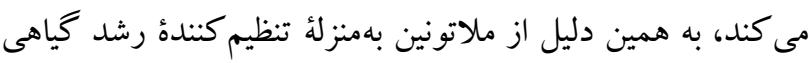

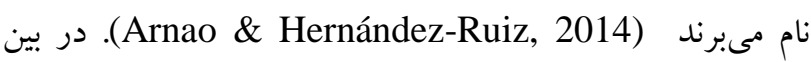
تمامى تنظيم كنندهاى رشد، ملاتونين داراى بيشترين ظرفيت آنتى - تاند

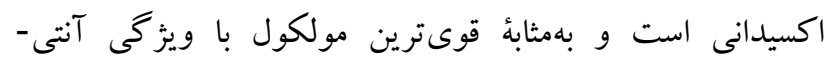

اكسيدانى شناخته شده است (Zhang \& Zhang, 2014). ملاتونين با كاهش واكنش فنتون، صدمات اكسيداتيو در مولكول-

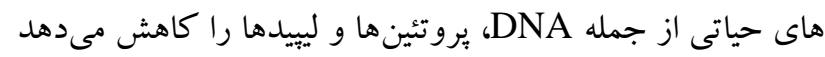
(Kennaway, 2017) غشاهاى كلرويلاستى و واكنشهاى كربو كسيلاسيون در فتوسنتز و و ثبات عمل كرد فتوسيستم ll، موجب كاهش تنش اكسيد ونسيداتيو مىشود (Liu et al., 2015). شواهدى وجود دارد كه تيمار

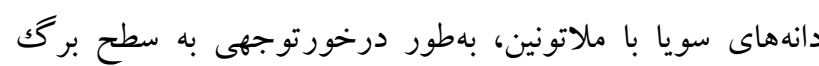

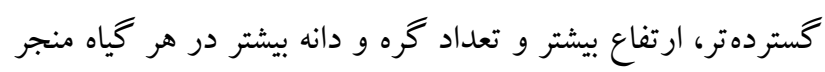

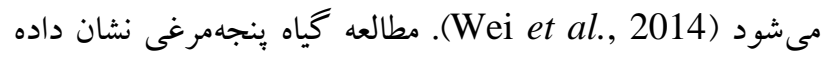

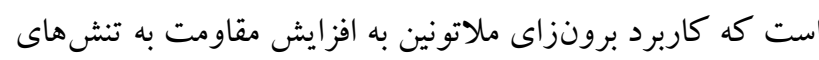

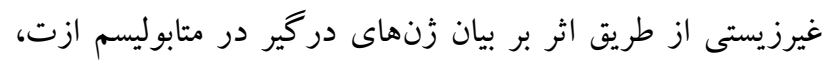

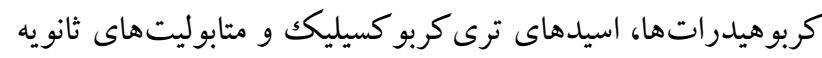
منجر مىشود. Sarrau و همكاران (2015) در مطالعه روى تأثير تمري همزمان ملاتونين، سالسيلات و جيبر الين روى اسانس و متابوليت-

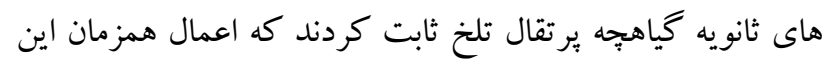
تنظيم كندههاى رشد بر فلاونوئيدها و تركيبات فنلى و نيز ظرفيت

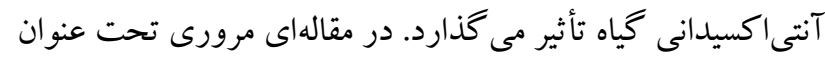
عمل كرد فيزيولوزيكى ملاتونين در كياهان به اثرات اين اندول آمين بر متابوليتهاى ثانويه گياهى اشاره شده است ( Arnao \& Hernández-Ruiz, 2006 ، اما بهطور كلى، مطالعات در زمينه اثرات ملاتونين بر متابوليتهاى ثانويه گياهى بسيار محدود است.

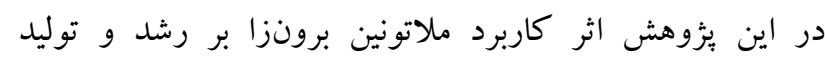

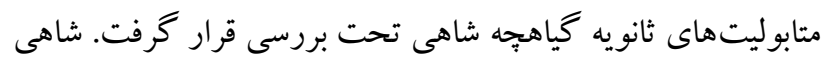

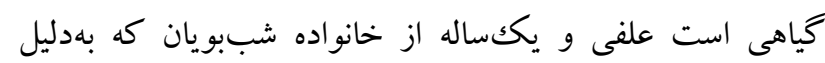

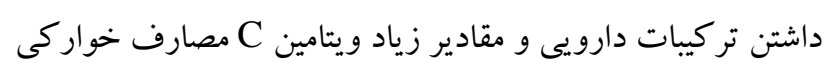
و دارويى دارد.
اثر محر ككهاى زيستى در گياه، حاصل تأثير آنها بر متابوليتهاى

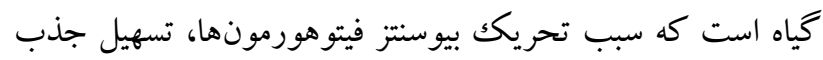
عناصر غذايى، تحريكك رشد ريشه و افزايش كيفيت و كميت

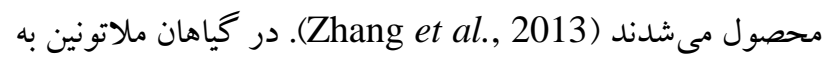
عنوان محرك زيستى شناخته شده كه موجب افزايش تحمل به به إنه

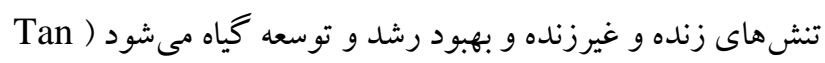

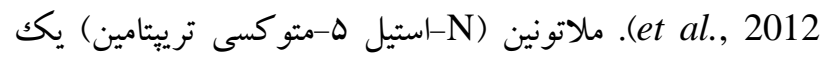
تركيب ايندولى است كه بهطور طبيعى در گياهان سنتز مىشود Posmyk \& Janas, 2008)

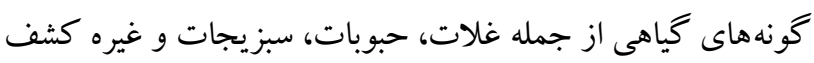

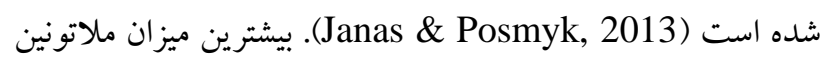

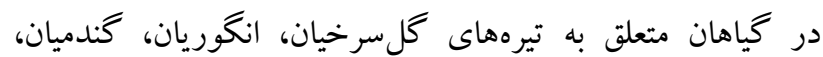
كرفسيان و كلميان شناسايى شده است (Nawaz et al., 2015). شواهد متعددى از نقش حفاظتى ملاتونين در گياهان وجود دارد.

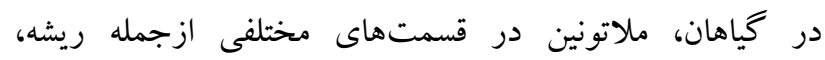

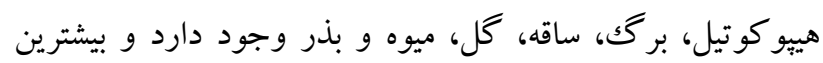
Arnao \& ( ميزان ملاتونين درونزا در بذر مشاهده شده است Hernández-Ruiz, 2007 حفاظت از جنين و بافتهاى توليدمثلى در برابر تنش اكسيداتيو

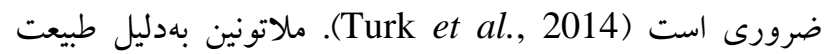
دو كانه آبدوستى و جربى دوستى، به راحتى از عرض غرولى الشا عبور

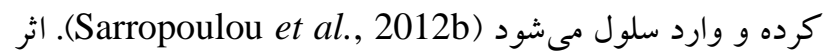
تحريك كنندگى و بازدارندگى ملاتونين به غلظت آن بستخى دارد Arnao \& Hernández-Ruiz, 2015) كيلاس، غلظت / • ميلىمولار ملاتونين سبب تحريك رشد ريشه، افزايش تعداد و طول ريشهها، افزايش رنخيزههاى فتوسنتزى،

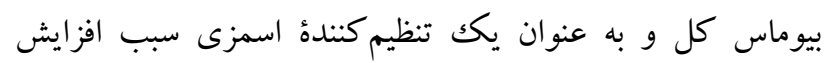

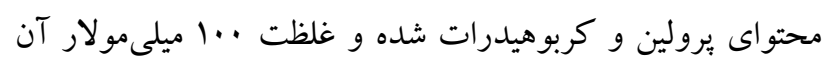
از رشد گياه جلو گيرى كرد (Sarropoulou et al., 2012b).

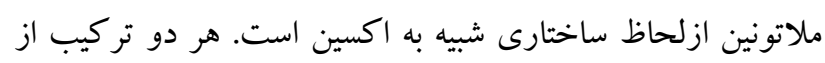

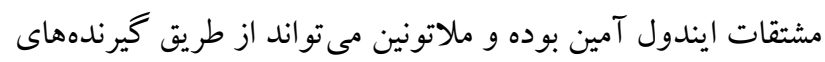

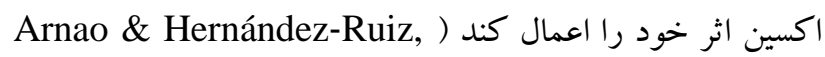

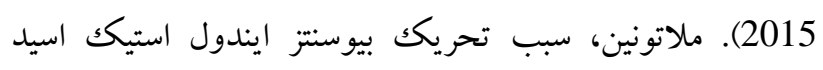

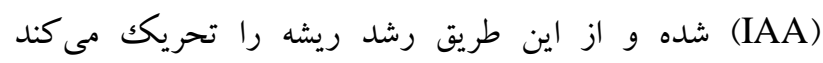


برگك عصاره گيرىشده در 10 ميلىليتر استن •A درصد با دستگاه

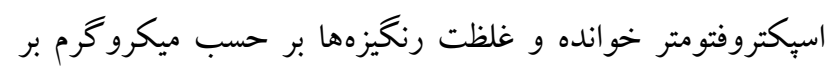
كرم وزنتر محاسبه شد.

Chla $=12.25 \mathrm{~A}_{663.2}-2.79 \mathrm{~A}_{646.8}$

$\mathrm{Chlb}=21.21 \mathrm{~A}_{646.8}-5.1 \mathrm{~A}_{663.2}$

Total Chl $=$ chla + chlb

Carotenids $=\left(1000 \mathrm{~A}_{470}-1.8\right.$ chla -85.02 chlb $) / 198$

فلاونوئيدهاى كل

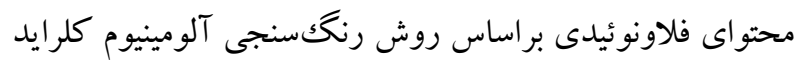

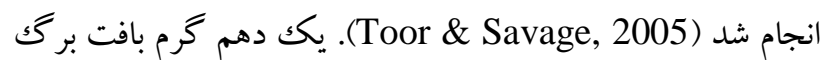

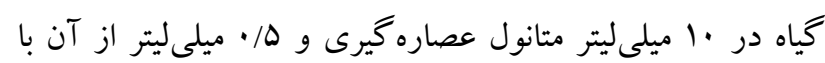

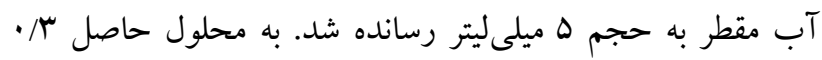

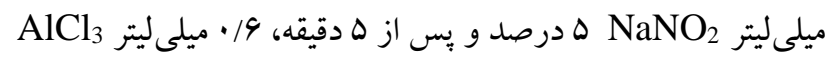

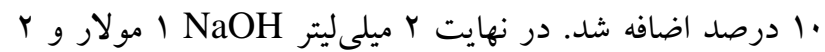

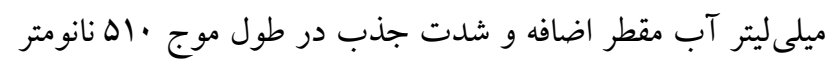
اندازهگيرى شد. غلظت نمونهها با استفاده از منحنى استاندارد

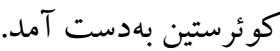

\section{محتواى آنتوسيانينها}

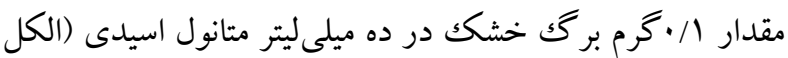

متيليك ه/ه9 درصد و كلريدريك اسيد خالص به نسبت 99 به ()

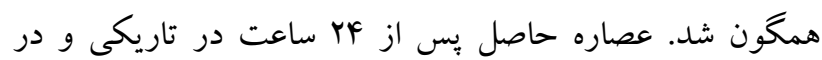

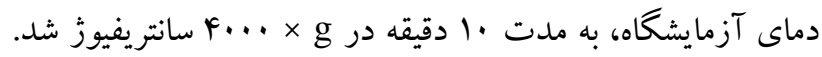

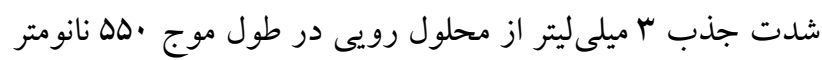
توسط اسبكتروفتومتر UV-Visble خوانده شد. براى محاسبه غلظت آنتوسيانينها از ضريب خاموشى معادل mM ${ }^{-1} \mathrm{Cm}^{-1}$ 1........

\section{تر كيبات فنلى كل}

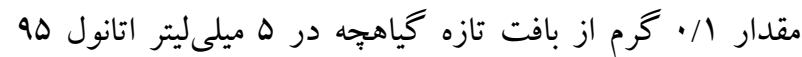

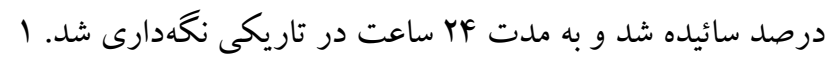
ميلى ليتر از محلول روئى، به ا ميلىليتر اتانول هه درصد اضافه و با سان آب دو بار تقطي، حجم محلول به هـ ميلى ليتر رسانيده شد. مقدار

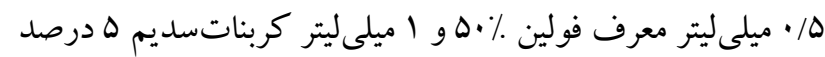

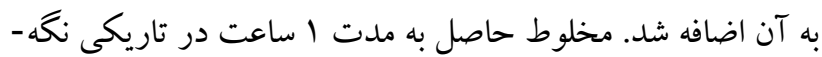

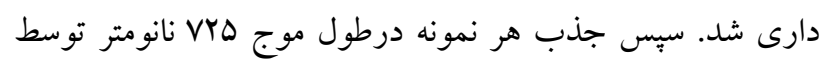
دستخاه اسبكتروفتومتر UV-Visible مدل 50 Cary خوانده شد. براى محاسبه غلظت تركيبات فنلى از منحنى استاندارد گاليك اسيد استفاده شد (Soland \& Laima, 1999).
بهمنظور بررسى اثر ملاتونين بر ويزگگ هاى رشدى و توليد

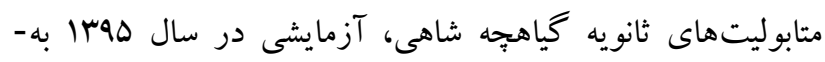
صورت فاكتوريل در قالب طرح كاملاً تصادفى در ب تكرار انجام

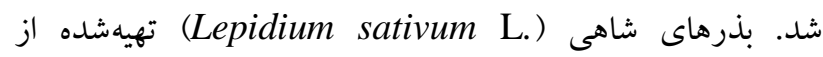
شركت پֶاكان بذر اصفهان به مدت .ب ثانيه در هييو كلريت سديم

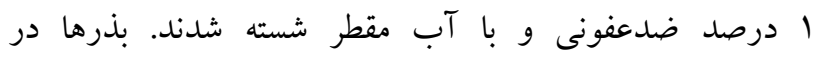
كلدانهايى با قطر rاسانتىمتر حاوى ماسه بادى شسته در شرايط

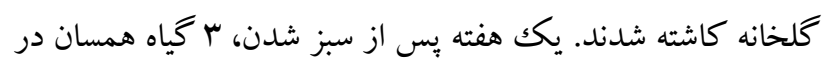

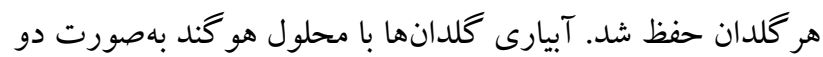
بار در هفته انجام شد. در هفته دوم، محلولياشى ملاتونين روى

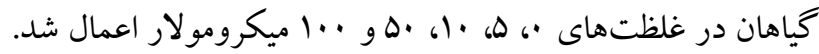

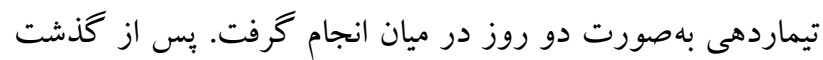

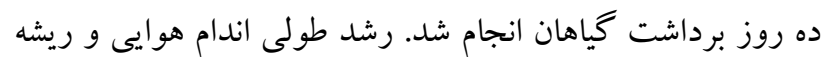

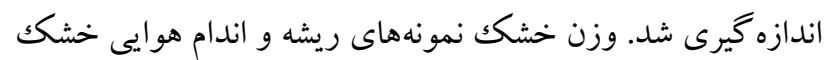

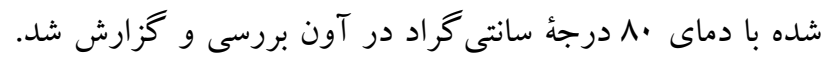

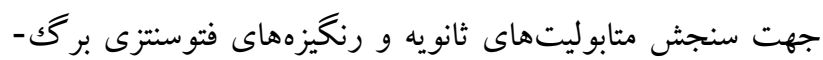
هاى گياهان در نيتروزن مايع فريز و در فريزر ·لم- درجئ

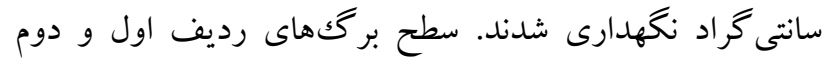

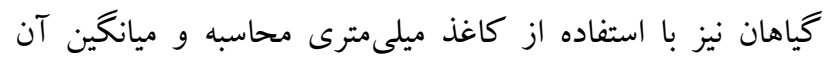
كزارش و مقايسه شد.

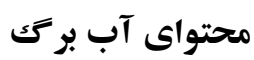
براى محاسبه درصد نسبى آب بافت، وزن تر اندام اندام هوايى گياهان

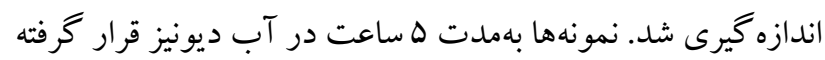

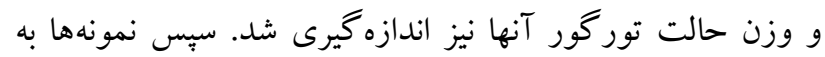

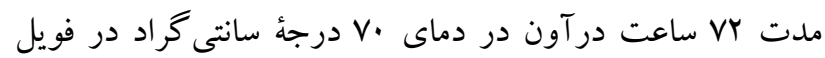
آلومينيمى خشك شدند. وزن خشك نمونهها اندازهيرى شد و Türkan et al., (با استفاده از رابطة زير محاسبه شد RWC .(2005

. . (وزن خشك-وزن تور گور /وزن

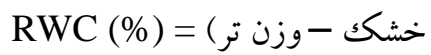

رنكيزههاى فتوسنتزى

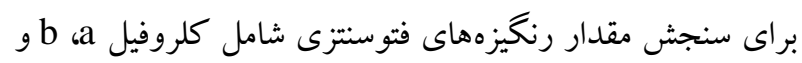
كلروفيل كل و كاروتنوئيدها (كاروتنوئيد و گز انتوفيل) با استفاده از روش استاندارد (Lichtenthaler, 1987)، مقدار جذب در

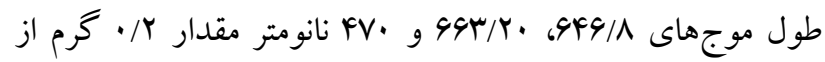


محتواى آب بركى منجر شد (P<0.05). تيمار ملاتونين با ضريب

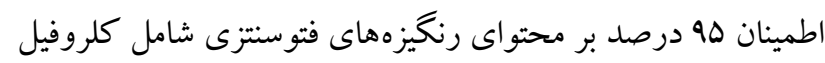
و b a a

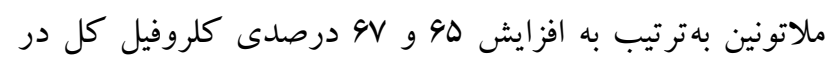

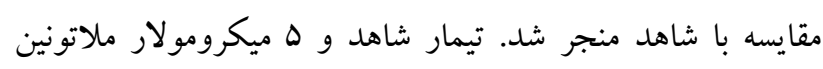

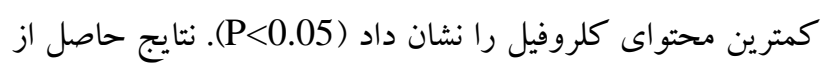

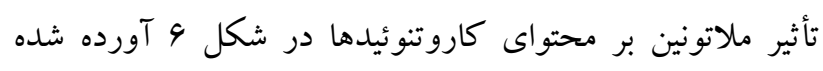

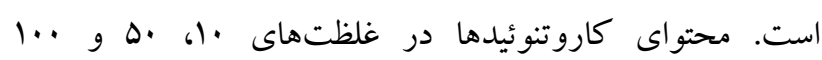
ميكرومولار ملاتونين بهطور معنىدارى در مقايسه با گرُوه شاهد

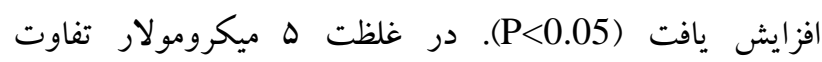

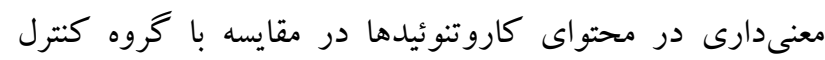

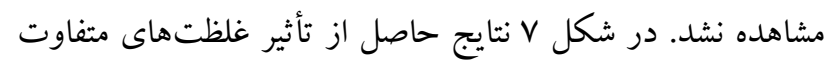

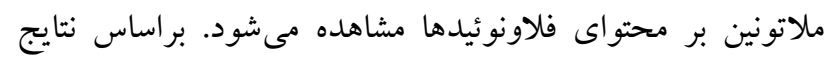

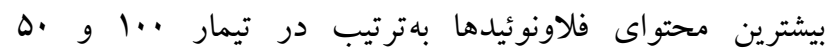

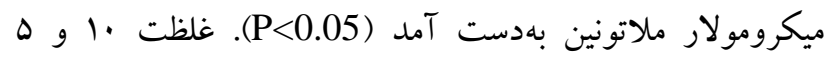

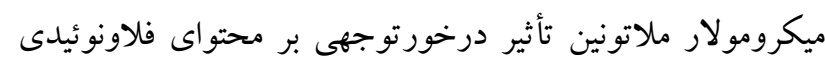

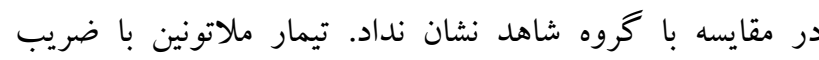

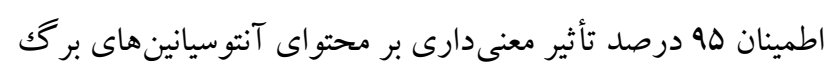

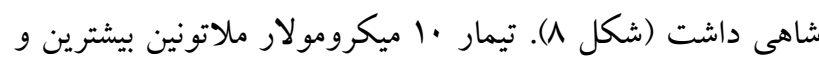
كروه شاهد كمترين مقدار آنتوسيانين را نشان داد. بين ساير گرووهها تفاوت معنى دارى در سطح معنى دارى P<0.05 مشاهده نشد. نتايج

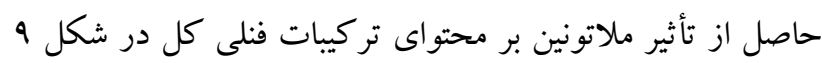

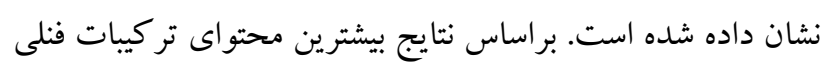

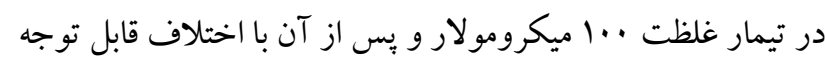

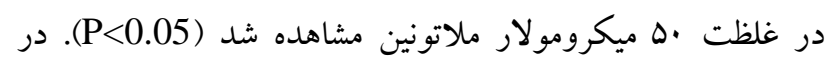

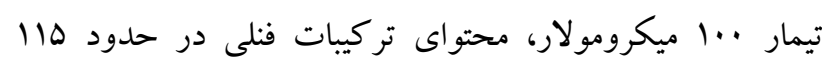

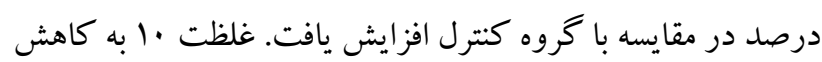

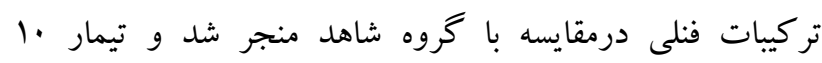
ميكرومولار تأثير درخورتوجهى محتواى تركيبات فنلى نداشت بنات

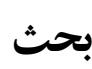

در اين بزوهش تأثير ملاتونين برونزا به عنوان يكك محرك زيستى

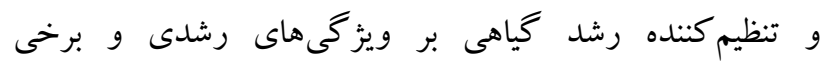

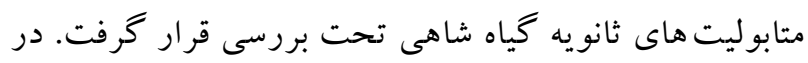

\section{بورسىهاى آمارى}

دادهها با استفاده از نرمافزار آمارى SPSS تحليل شد و با مشاهده تفاوت معنىدار در تحليل واريانس (ANOVA)، مقايسه ميانگين - دادها ها با استفاده از آزمون دانكن در سطح احتمال ها هـ درصد و و رسم

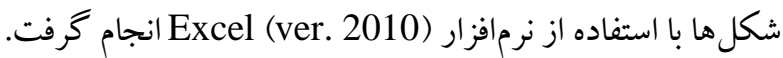

\section{نتايج}

نتايج حاصل از تحليل واريانس يككطرفه دادههاى رشدى و

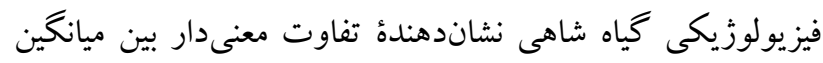

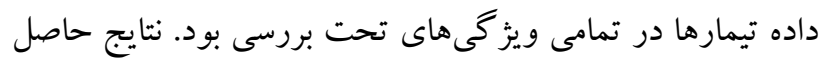

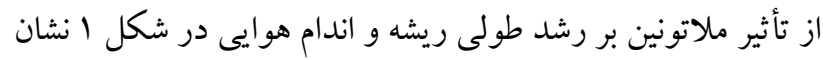

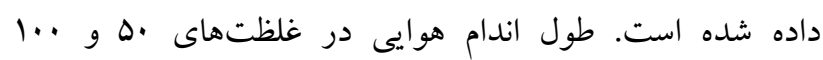

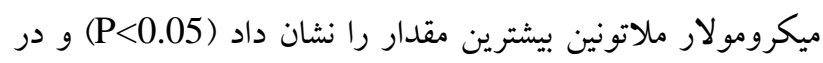
غلظت ها ميكرومو لار تفاوت معنىدارى در مقايسه با گروه كنترل نشان نداد. رشد طولى ريشه نيز در غلظتهاى له و و ل.

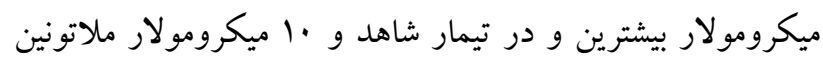
كمترين مقدار را نشان داد (شكل ()). همانطور كه در شكل r نشان داده شده است محلولياشى ملاتونين بر ميزان بيومس و وزن خشك ريشه و اندام هوايى مؤثر

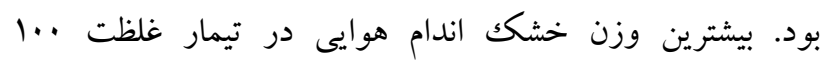

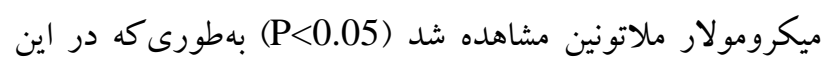
تيمار مقدار وزن خشك اندام هوايى در حدود \%4 در مقايسه با

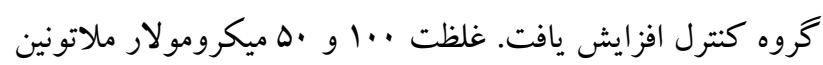

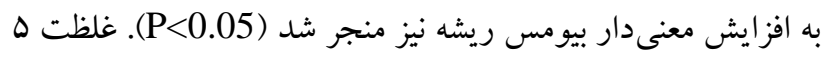

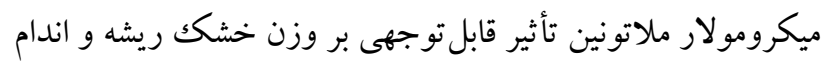

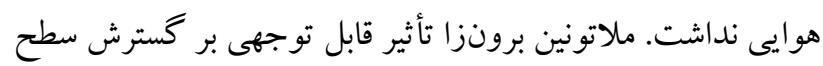

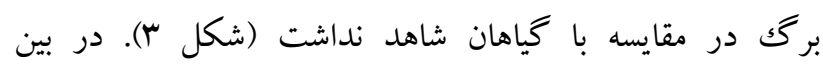
غلظتهاى ملاتونين به كار رفثه، تيمار • إميكرومولار بيشترين تأثير

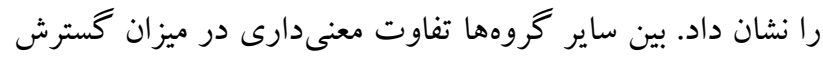
سطح برگك شاهى مشاهده نشد (P<0.05). در شكل \& نتايج حاصل از تأثير غلظتهاى متفاوت ملاتونين بر ماهد محتواى آب برگك آورده شده است. براساس نتايج، بيشترين

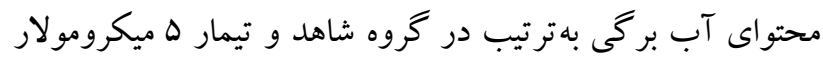

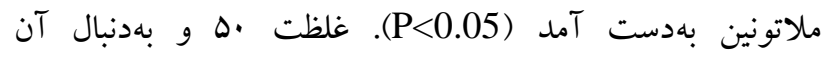
غلظتهاى ..1 و .| ميكرومولار ملاتونين به كاهش معنىدار 


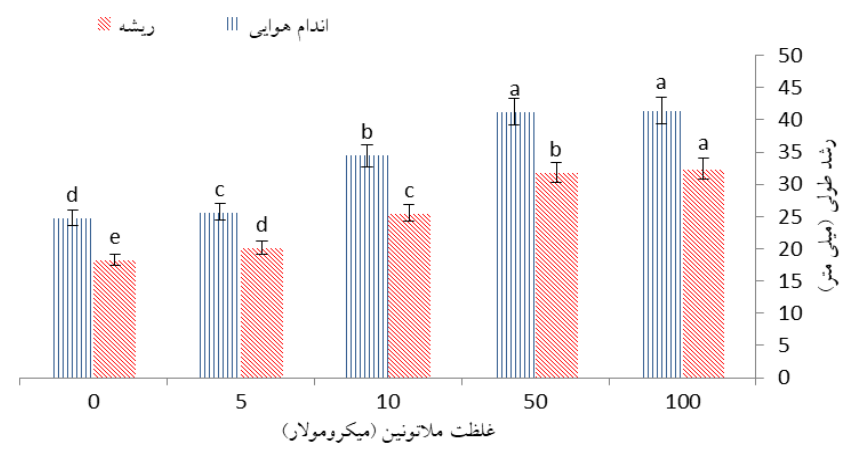

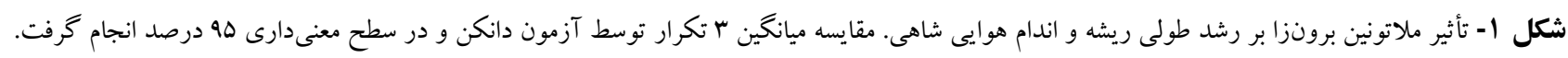

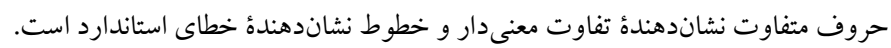

Fig. 1. Effect of exogenous melatonin treatment on root and shoot length of Lepidium sativum. Mean comparison of three replications was done by Duncan test and at a significant level of $95 \%$. Different letters indicate a significant difference and error bars show standard error of means.

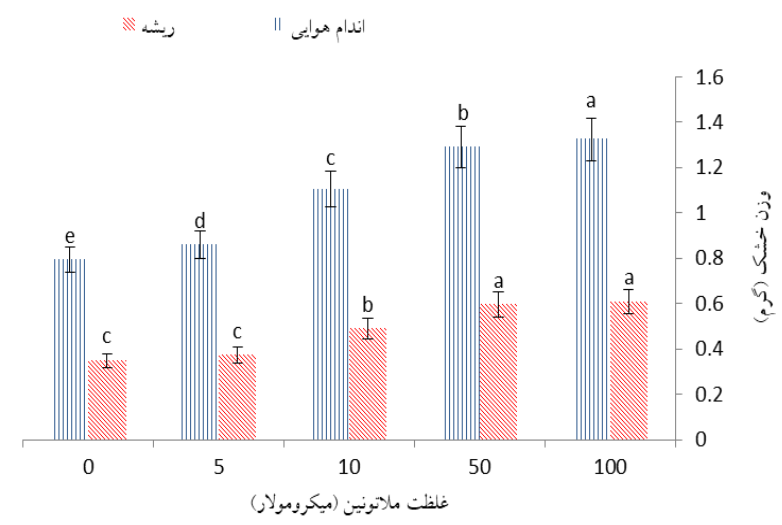

شكل r- تأثير ملاتونين برونزا بر توليد زى توده ريشه و اندام هوايى شاهى. مقايسه ميانگين ب تكرار توسط آزمون دانكن و در سطح معنىدارى هو دروصد انجام

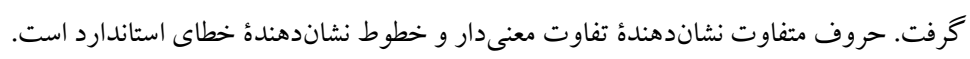

Fig. 2. Effect of exogenous melatonin treatment on biomass production in Lepidium sativum plants. Mean comparison of three replications was done by Duncan test and at a significant level of 95\%. Different letters indicate a significant difference and error bars show standard error of means.

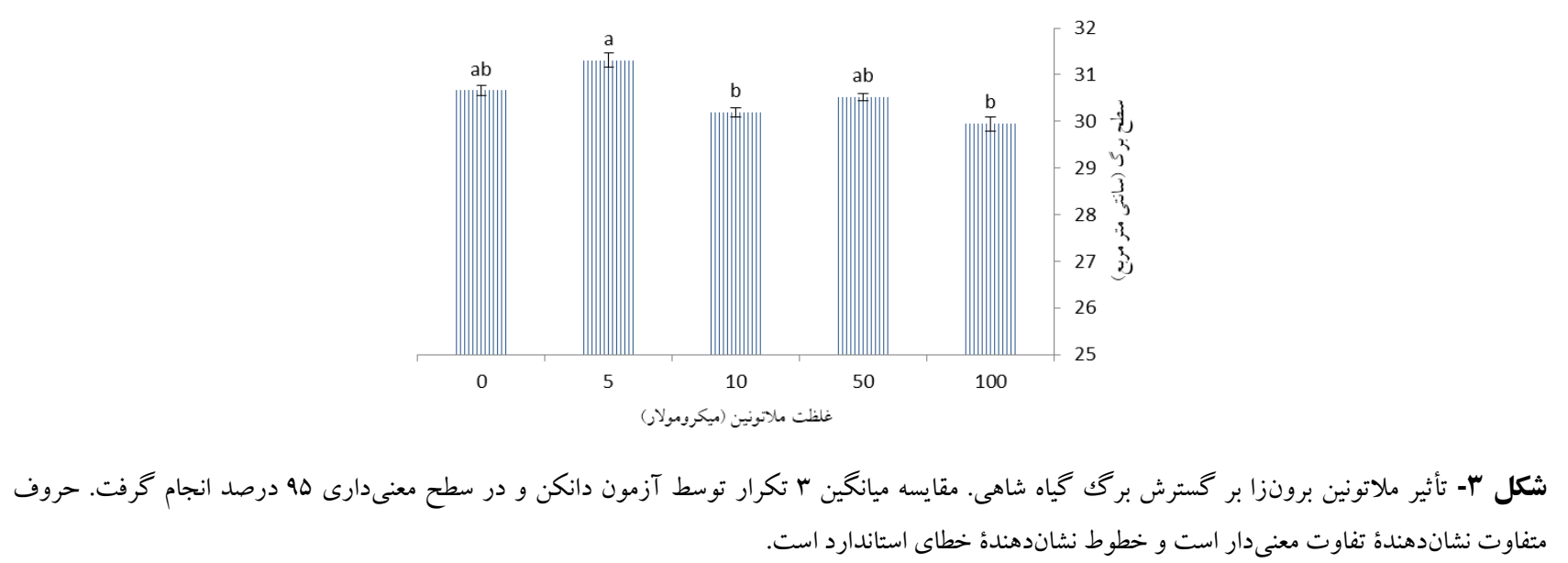

Fig. 3. Effect of exogenous melatonin treatment on leaf expansion in Lepidium sativum. Mean comparison of three replications was done by Duncan test and at a significant level of $95 \%$. Different letters indicate a significant difference and error bars show standard error of means. 


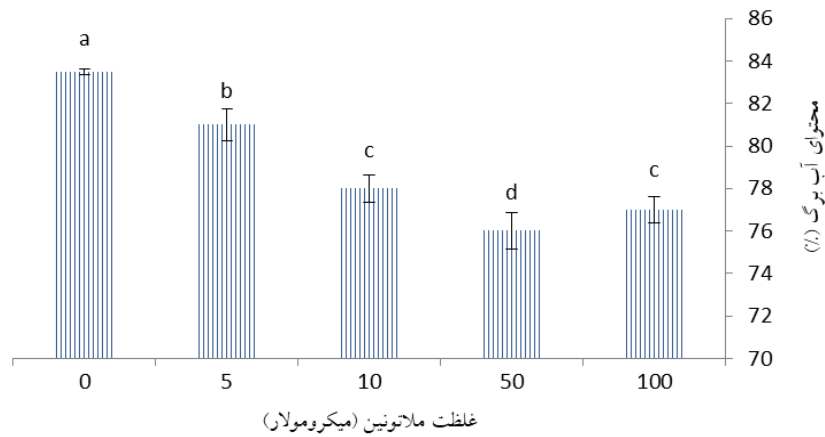

شكل ع- تأثير ملاتونين برونزا بر محتواى آب برگك شاهى. مقايسه ميانگين r تكرار توسط آزمون دانكن و در سطح معنىدارى هه درصد انجام گرفت. حروف

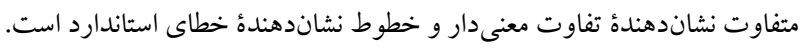

Fig. 4. Effect of exogenous melatonin treatment on leaf water content in Lepidium sativum. Mean comparison of three replications was done by Duncan test and at a significant level of 95\%. Different letters indicate a significant difference and error bars show standard error of means.

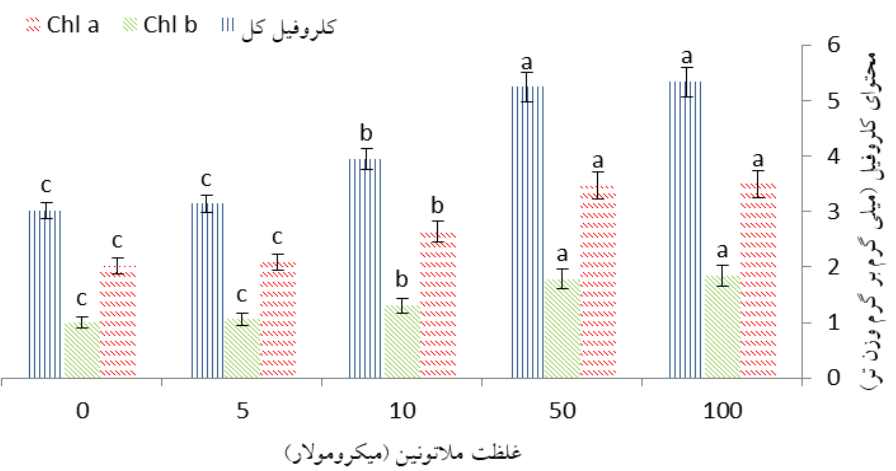

شكل 0- تأثير ملاتونين برونزا بر محتواى كلروفيل Chl a) a)، كلروفيل Chl b) b) و كلروفيل كل (total Chl) بركى شاهى. مقايسه ميانگين ب تكرار توسط آزمون دانكن و در سطح معنى دارىه درصد انجام گرفت. حروف متفاوت نشاندهنده تفاوت معنى دار و خطوط نشاندهندئ خطاى استاندارد است.

Fig. 5. Effect of exogenous melatonin treatment on chlorophyll a (Chl a), b (Chl b) and total chlorophyll (Total Chl) content in Lepidium sativum. Mean comparison of three replications was done by Duncan test and at a significant level of $95 \%$. Different letters indicate a significant difference and error bars show standard error of means.

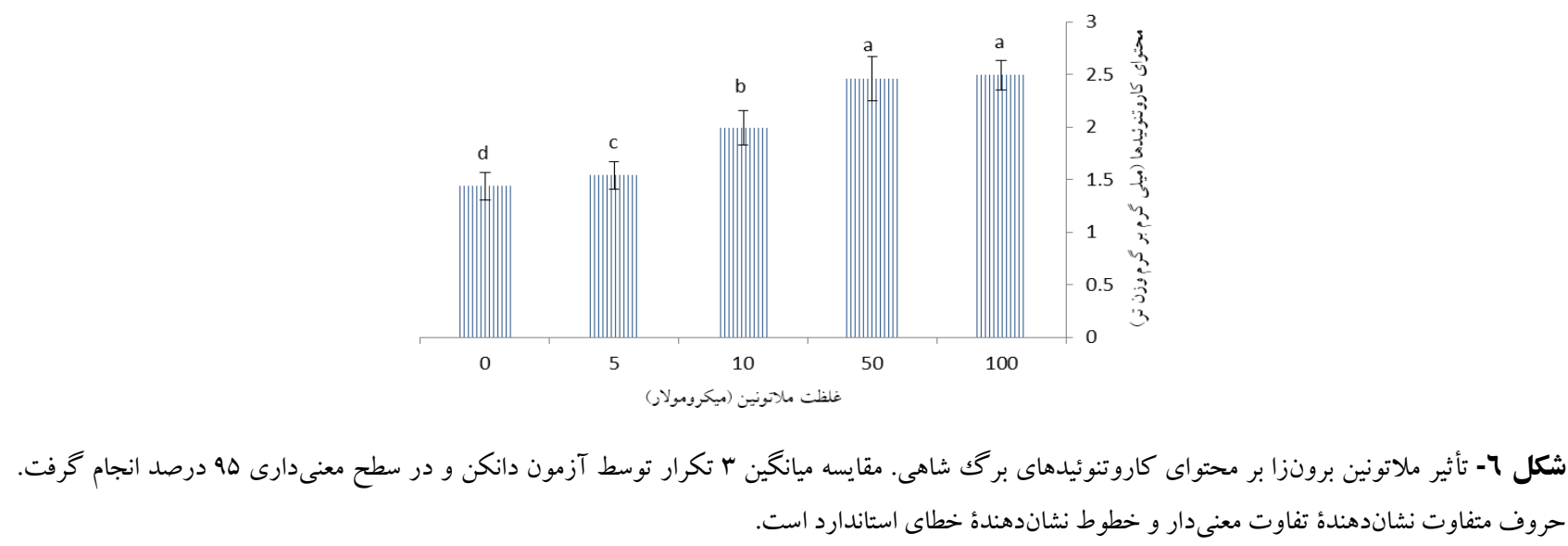

Fig. 6. Effect of exogenous melatonin treatment on carotenoids content in Lepidium sativum leaves. Mean comparison of three replications was done by Duncan test and at a significant level of $95 \%$. Different letters indicate a significant difference and error bars show standard error of means. 


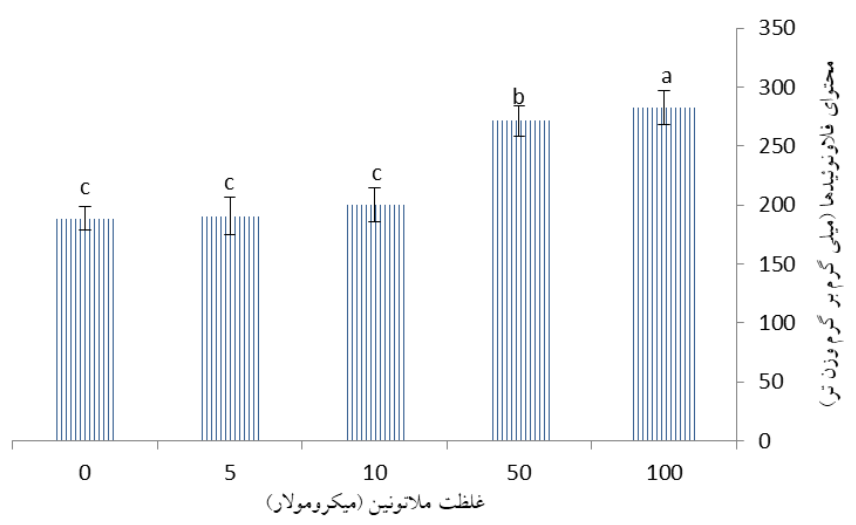

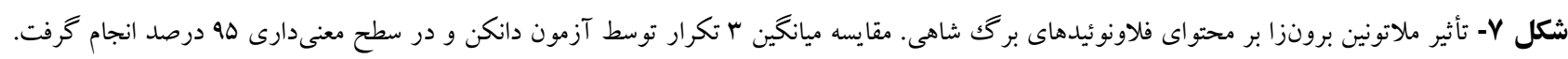

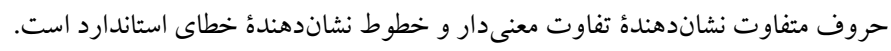

Fig. 7. Effect of exogenous melatonin treatment on flavonoids content in Lepidium sativum leaves. Mean comparison of three replications was done by Duncan test and at a significant level of 95\%. Different letters indicate a significant difference and error bars show standard error of means.

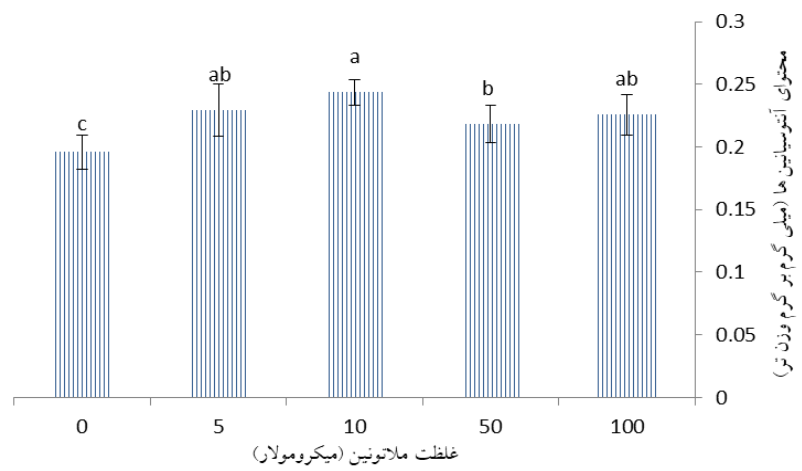

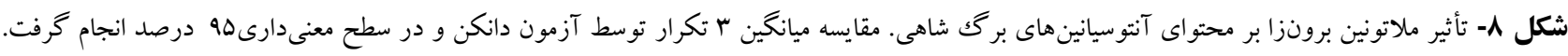

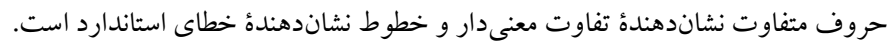

Fig. 8. Effect of exogenous melatonin treatment on anthocyanins content in Lepidium sativum leaves. Mean comparison of three replications was done by Duncan test and at a significant level of $95 \%$. Different letters indicate a significant difference and error bars show standard error of means.

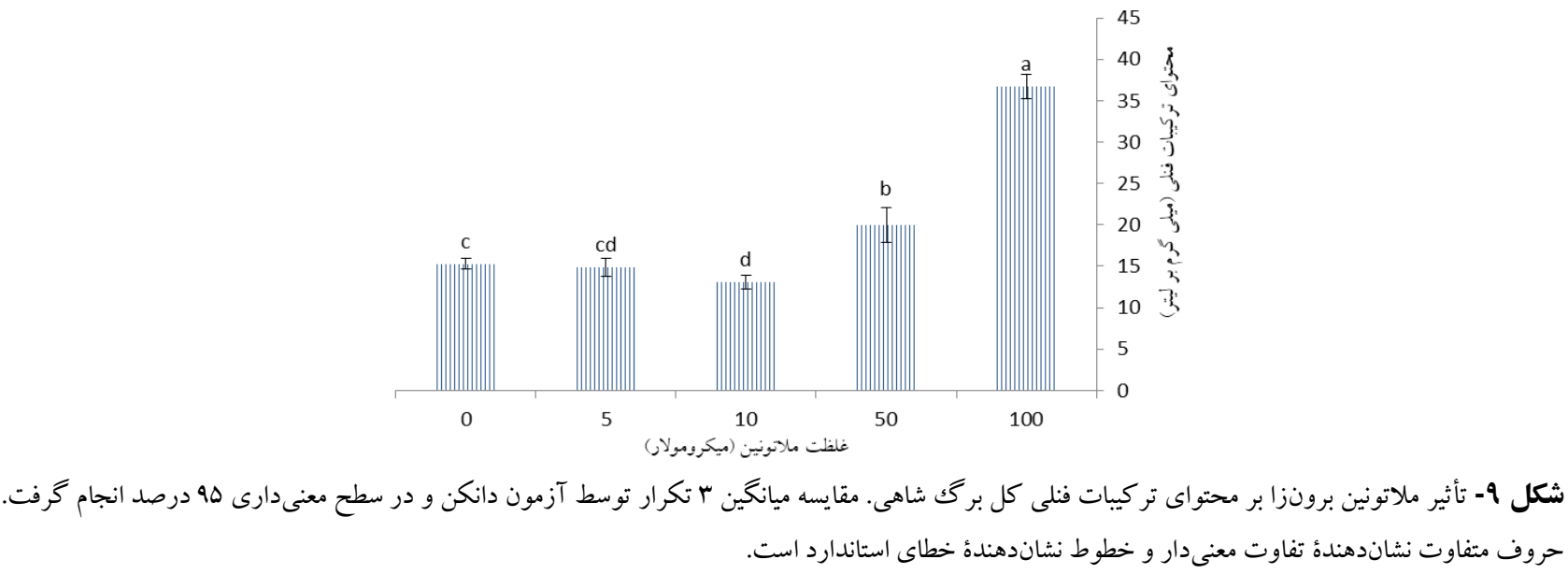

Fig. 9. Effect of exogenous melatonin treatment on leaf water content in Lepidium sativum leaves. Mean comparison of three replications was done by Duncan test and at a significant level of 95\%. Different letters indicate a significant difference and error bars show standard error of means. 
يون، نفوذيذيرى غشا، فعاليت آنزيمها و هورمونها، ميزان رشد و

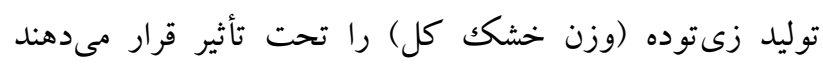
(Zhang et al., 2013)

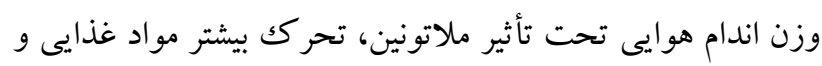

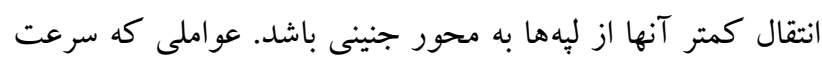

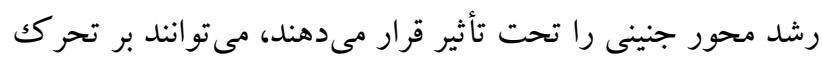

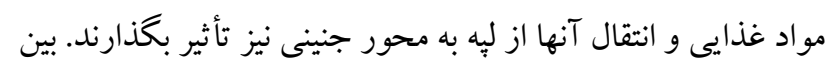

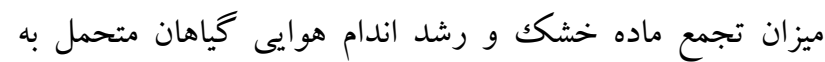

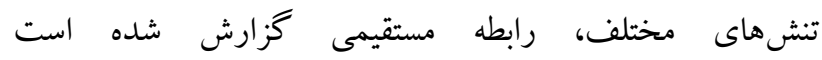
(Nagashiro \& Shibata, 1995) برگك گياه با افزايش غلظت ملاتونين كاهش يافت. بنابراين بهنظر مىرسد افزايش رشد گياه بيش از آنكه وابسته به محتواى آب كآب كياه باشد، تحت تأثير بهبود تغذيه معدنى و توليد زى توده گياه است.

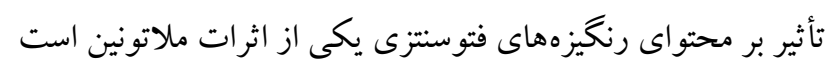

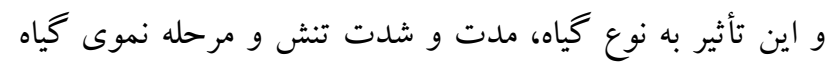

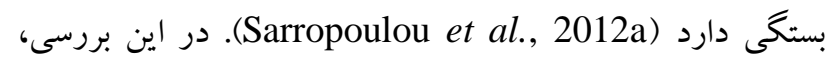

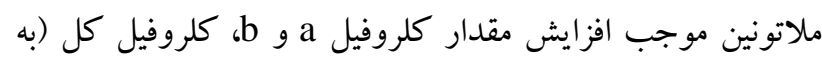

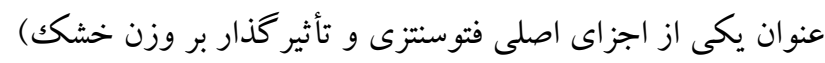
و كاروتنوئيدها در شاهى شد. اين اثر نشاندهندة توانايى ملاتونين براى بهبود رشد است. Sarropoulou و همكاران (2012a) كزارش كردند كه تيمار ملاتونين در غلظت مناسب، علاوه بر اينكه

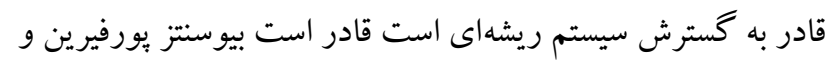
كلروفيل را افزايش دهد. از طرفى مشخص شده است كه ييشتيمار ملاتونين از فعاليت آنزيم كلروفيلاز و آنزيم فئوفوربيداكسيزناز

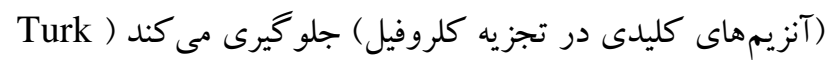
et al., 2014 كلروفيل، به تعويق انداختن بيرى برك، حفظ ثبات و و عمل كرد

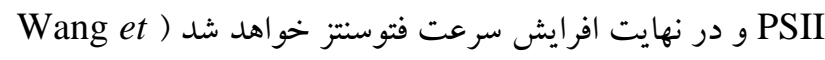
al., 2007 القاى سنتز كاروتنوئيدها در شرايط تنش توسط نوسط

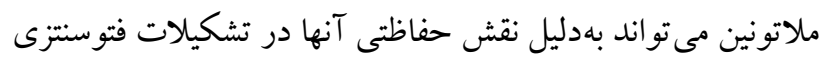

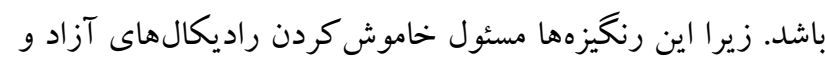

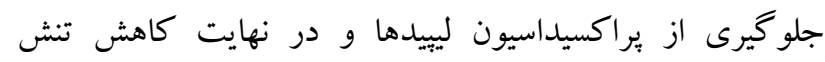

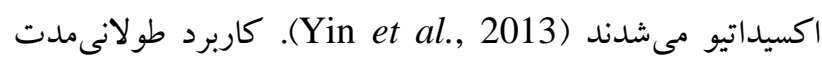
ملاتونين روى درختان يكساله سيب تحت تنش خشكى

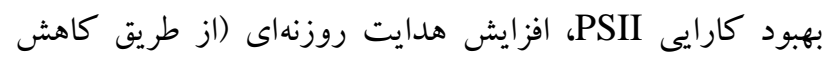

بررسى گياه كلم، Zhang و همكاران (2014) گزارش كردند كه ملاتونين برونزا توسط گياه جذب مىشود و و از اين طريق بر ميزان

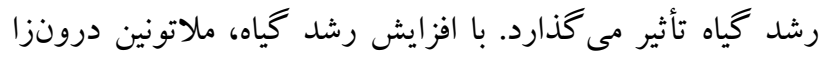
افزايش مىيابد كه مىتواند مبين نقش اين تركيب در رشد رئ رياه

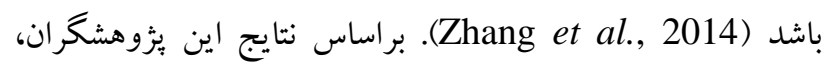
ملاتونين بر رشد طولى ريشه و شاخه و وزن خشك كياه اثر معنى -

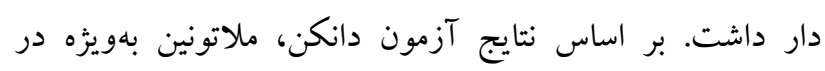

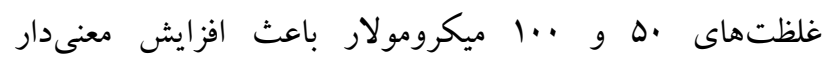

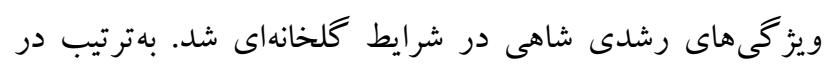

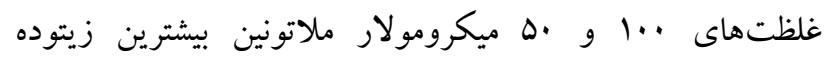

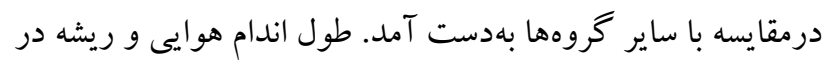
غلظتهاى بالاى ملاتونين بيشترين مقدار را نشان داد. ملاتونين موجب ريشهزايى، تحريك رشد ريشه و اندام هوايى و به تأخير

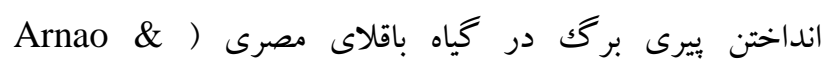
(Zhang et al., 2013) (Hernández-Ruiz, 2014 آرابيدويسيس و برنج شد. مكانيسمى كه ملاتونين رشد ريشه و و بخش هوايى را در گياهان افزايش مىدهد، بخوبى شناخته نشده

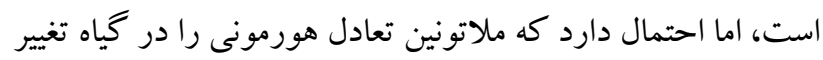
داده و تحت شرايط تنش، سبب افزايش اكسين و سيتوكينين شود (Hernandez-Ruiz et al., 2004). كزارش شده است كه إن ملاتونين از طريق تأثير بر افزايش ترشح هورمونهاى محرك رشد مانند ايندول استيكك اسيد، سيتو كينين، جيبرلين، اكسين، تر كيبات

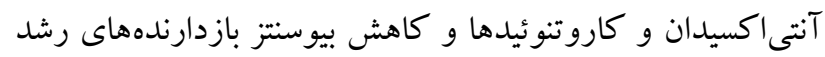
ازجمله اتيلن، ميزان تقسيم سلولى بافتهاى مريستمى را افزايش مىدهد (Li et al., 1994). ملاتونين ازلحاظ ساختارى شبيه اكسين است و اثراتى مشابه آن دارد كه موجب تشكيل ريشه و واله

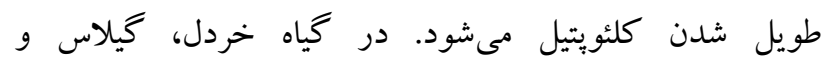

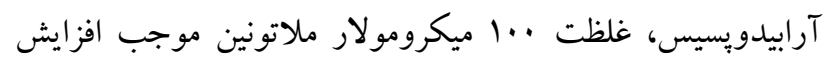
رشد ريشه و اندام هوايى شده در حاليكه غلظتهاى بالاتر، بازدارنده رشد ريشه و اندام هو ايى بودند (Chen et al., 2003).

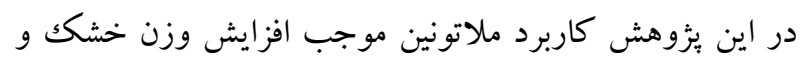

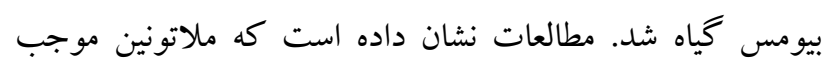
افزايش وزن خشك كياهجه شيرين بيان (Afreen et al., 2006) و سيب (Wang et al., 2007) مىشود. تركيبات ايندولى (از

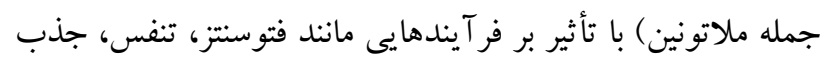


براساس نتايج، ملاتونين برونزا قادر به بهبود ويزگ گهاى رشدى

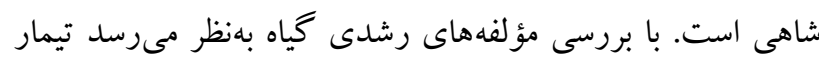

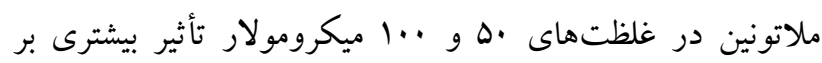

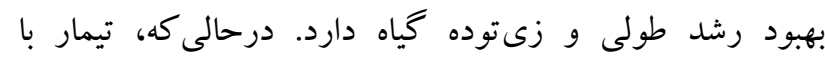

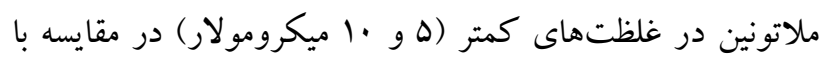

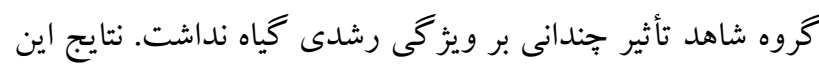

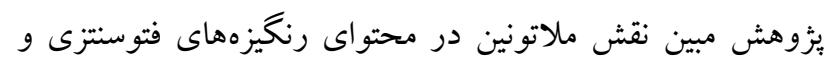

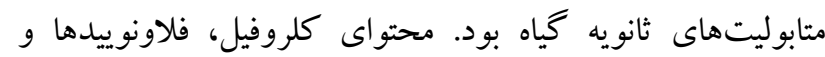
تركيبات فنلى در غلظتهاى بالاتر ملاتونين بهطور درخورتوجهى

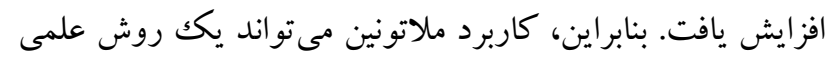
و مقرون به صرفه در بهبود كيفيت محصولات كشاورزى كشور

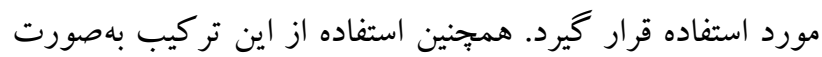
ياششى جهت افزايش رشد و تحمل گياه شاهى يِيشنهاد مى شود.

\section{سياسگز ارى}

بدينوسيله از يززوهشَاه علوم، تكنولوزى بيشرفته و علوم محيطى،

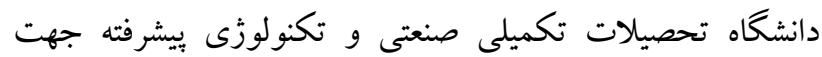

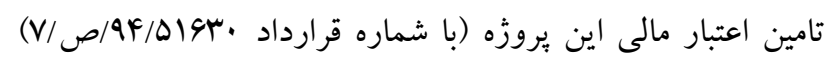

$$
\text { قدردانى مى شود. }
$$

\section{REFERENCES}

Afreen, F., Zobayed, S. and Kozai, T. 2006. Melatonin in Glycyrrhiza uralensis: response of plant roots to spectral quality of light and UV-B radiation. - J. Pineal. Res. 41: 108-115.

Aguilera, Y., Herrera, T., Liébana, R., Rebollo-Hernanz, M., Sanchez-Puelles, C. and Martín-Cabrejas, M.A. 2015. Impact of melatonin enrichment during germination of legumes on bioactive compounds and antioxidant activity. - J. Agric. Food Chem. 63: 7967 7974.

Arnao, M.B. and Hernández-Ruiz, J. 2006. The physiological function of melatonin in plants. - Plant Signal. Behav. 1: 89-95.

Arnao, M.B. and Hernández-Ruiz, J. 2014. Melatonin: plant growth regulator and/or biostimulator during stress? - Trends Plant Sci. 19: 789-797.

Arnao, M.B. and Hernández-Ruiz, J. 2007. Melatonin promotes adventitious-and lateral root regeneration in etiolated hypocotyls of Lupinus albus L. - J. Pineal. Res. 42: 147-152.

Arnao, M.B. and Hernández-Ruiz, J. 2015. Functions of melatonin in plants: a review. - J. Pineal. Res. 59: 133-150.

Bajwa, V.S., Shukla, M.R., Sherif, S.M., Murch, S.J. and Saxena, P.K. 2014. Role of melatonin in alleviating
سطح ABA) و در نتيجه انتشار CO به داخل گياه موجب حفظ

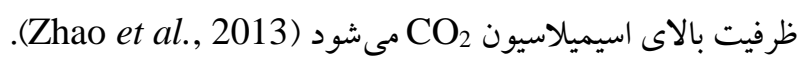
نتايج اين وُروهش نشاندهندة نقش مؤثر ملاتونين برونزا بر

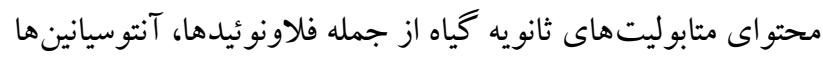
و تركيبات فنلى بود. در اين بررسى ملاتونين بهويزه در غلظتهاى

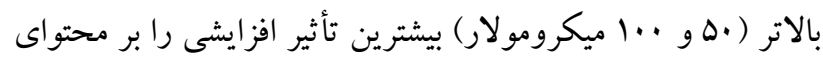

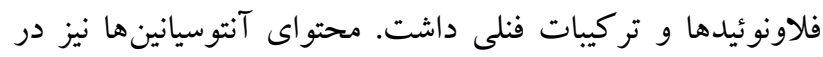

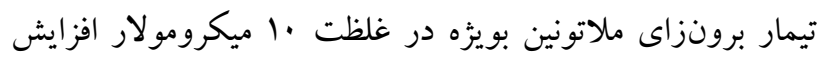

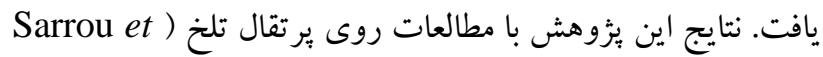

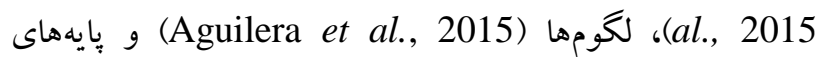
كيلاس (Zhang et al., 2016) مطابقت دارد. در برتقال تلخ، ملاتونين ها ميكرومولار بيشترين تأثير را بر محتواى تركيبات فنلى

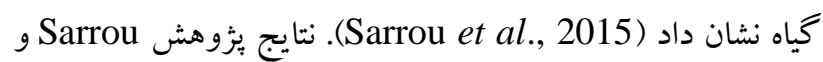
همكاران (2015) نشان داد كه در ير تقال تلخ تيمارهاى ملاتونين،

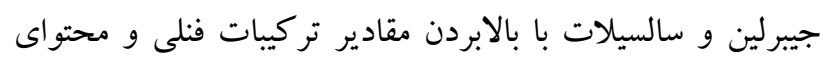

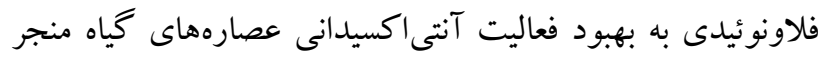
مى شود. آنتوسيانينها بهور مستقيم در قابليت آنتى اكسيدانى خياه نقش دارند (Hu et al., 2016). نشان دادند كه ملاتونين مىتواند محتواى آنتوسيانين گياه را در كلم بهبود بخشد (Zhang et al., 2016). مطالعات اين محققان نشان داد كه بيان زنهاى دركير در بيوسنتز آنتوسيانينها در تيمار

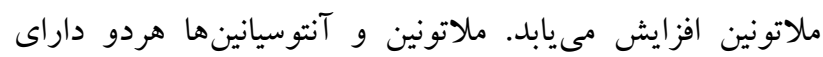
قابليت آنتىاكسيدانى بوده و تيمار ملاتونين نه تنها بيان زنهاى

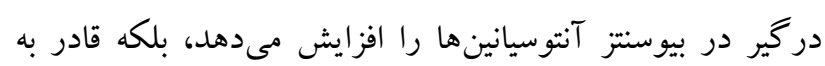

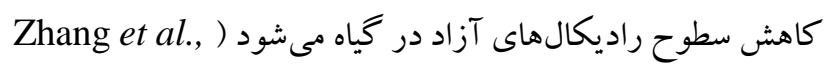
2016). به دليل تأثيرى كه ملاتونين بر محتواى تركيبات ثانويه

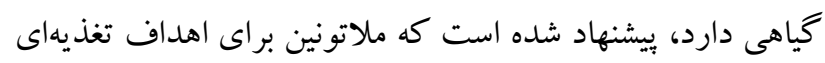
در حوزه كشاورزى مورد استفاده قرار گيرد ( ) Wang et al., 2013). براساس نتايج اين ئزوهش در مورد نقش مورد ملاتونين درد

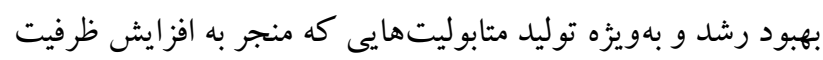

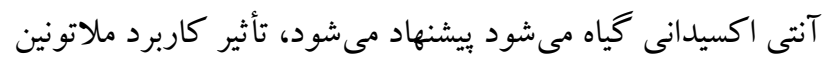
بر محصولات مهم كشاورزى در شرايط تنش تحت بررسى قرار كيرد. نتيجه كيرى 
cold stress in Arabidopsis thaliana. - J. Pineal. Res. 56: $238-245$.

Chen, G., Huo, Y., Tan, D.-X., Liang, Z., Zhang, W. and Zhang, Y. 2003. Melatonin in Chinese medicinal herbs. - Life Sci. 73: 19-26.

Hernandez-Ruiz, J., Cano, A. and Arnao, M.B. 2004. Melatonin: a growth-stimulating compound present in lupin tissues. - Planta 220: 140-144.

Hu, Y., Deng, L., Chen, J., Zhou, S., Liu, S., Fu, Y., Yang, C., Liao, Z. and Chen, M. 2016. An analytical pipeline to compare and characterize the anthocyanin antioxidant activities of purple sweet potato cultivars. - Food Chem. 194: 46-54.

Janas, K.M. and Posmyk, M.M. 2013. Melatonin, an underestimated natural substance with great potential for agricultural application. - Acta Phys. Plant. 35: 3285-3292.

Kennaway, D.J. 2017. Are the proposed benefits of melatonin-rich foods too hard to swallow? - Critic. Rew. Food Sci. Nut. 57: 958-962.

Li, Q., Levy, A.D., Battaglia, G., Cabrera, T.M. and Van de Kar, L.D. 1994. Attenuation of hormone responses to the 5-HT 1A agonist ipsapirone by long-term treatment with fluoxetine, but not desipramine, in male rats. - Biol. Psychiat. 36: 300-308.

Lichtenthaler, H.K. 1987. Chlorophylls and carotenoids: pigments of photosynthetic biomembranes. - Methods in Enzymology 148: 350-382.

Liu, N., Jin, Z., Wang, S., Gong, B., Wen, D., Wang, X., Wei, M. and Shi, Q. 2015. Sodic alkaline stress mitigation with exogenous melatonin involves reactive oxygen metabolism and ion homeostasis in tomato. - Sci. Hortic. 181: 18-25.

Nagashiro, C. and Shibata, F. 1995. Influence of flooding and drought conditions on herbage yield and quality of phasey bean (Macroptilium lathyroides (L.) Urb.). - J. Japan. Soc. Grassland Sci. (Japan). 41: 218-225.

Nawaz, M.A., Huang, Y., Bie, Z., Ahmed, W., Reiter, R.J., Niu, M. and Hameed, S. 2015. Melatonin: current status and future perspectives in plant science. - Front. Plant Sci. 6: 1-12

Posmyk, M.M. and Janas, K.M. 2008. Melatonin in plants. - Acta Phys. Plant. 31: 1-12

Sarropoulou, V., Dimassi-Theriou, K., Therios, I. and Koukourikou-Petridou, M. 2012a. Melatonin enhances root regeneration, photosynthetic pigments, biomass, total carbohydrates and proline content in the cherry rootstock PHL-C (Prunus avium $\times$ Prunus cerasus). - Plant Phys. Biochem. 61: 162-168.

Sarropoulou, V.N., Therios, I.N. and Dimassi-Theriou, K.N. 2012b. Melatonin promotes adventitious root regeneration in in vitro shoot tip explants of the commercial sweet cherry rootstocks CAB-6P (Prunus cerasus L.), Gisela 6 (P. cerasus $\times P$. canescens $)$, and MxM 60 (P. avium $\times$ P. mahaleb). - J. Pineal. Res. 52: 38-46.

Sarrou, E., Chatzopoulou, P., Dimassi-Theriou, K., Therios, I. and Koularmani, A. 2015. Effect of melatonin, salicylic acid and gibberellic acid on leaf essential oil and other secondary metabolites of bitter orange young seedlings. - J. Essen. Oil Res. 27: 487496.

Soland, S. and Laima, S. 1999. Phenolics and cold tolerance of Brassica napus. - Plant Agric. 1: 1-5.

Tan, D.-X., Hardeland, R., Manchester, L.C., Korkmaz, A., M., S., Rosales-Corral, S. and Reiter, R.J. 2012. Functional roles of melatonin in plants, and perspectives in nutritional and agricultural science. J. Exp. Bot. 63: 577-597.

Toor, R.K. and Savage, G.P. 2005. Antioxidant activity in different fractions of tomatoes. - Food Res. Int. 38: 487-494.

Turk, H., Erdal, S., Genisel, M., Atici, O., Demir, Y. and Yanmis, D. 2014. The regulatory effect of melatonin on physiological, biochemical and molecular parameters in cold-stressed wheat seedlings. - Plant Growth Regul. 74: 139-152.

Türkan, I., Bor, M., Özdemir, F. and Koca, H. 2005. Differential responses of lipid peroxidation and antioxidants in the leaves of drought-tolerant $P$. acutifolius gray and drought-sensitive $P$. vulgaris L. subjected to polyethylene glycol mediated water stress. - Plant Science. 168: 223-231.

Wagner, G.J. 1979. Content and vacuole/extravacuole distribution of neutral sugars, free amino acids, and anthocyanin in protoplasts. - Plant Physiol. 64: 88-93.

Wang, P., Sun, X., Li, C., Wei, Z., Liang, D. and Ma, F. 2013. Long-term exogenous application of melatonin delays drought-induced leaf senescence in apple. $-\mathbf{J}$. Pineal Res. 54: 292-302.

Wang, Y.-L., Wang, X.-D., Zhao, B. and Wang, Y.-C. 2007. Reduction of hyperhydricity in the culture of Lepidium meyenii shoots by the addition of rare earth elements. - Plant Growth Regul. 52: 151-159.

Wei, W., Li, Q.-T., Chu, Y.-N., Reiter, R.J., Yu, X.-M., Zhu, D.-H., Zhang, W.-K., Ma, B., Lin, Q. and Zhang, J.-S. 2014. Melatonin enhances plant growth and abiotic stress tolerance in soybean plants. - J. Exp. Bot. 66: 695-707.

Yin, L., Wang, P., Li, M., Ke, X., Li, C., Liang, D., Wu, S., Ma, X., Li, C. and Zou, Y. 2013. Exogenous melatonin improves Malus resistance to Marssonina apple blotch. - J. Pineal. Res. 54: 426-434.

Zhang, H.M. and Zhang, Y. 2014. Melatonin: a well-documented antioxidant with conditional pro-oxidant actions. - J. Pineal. Res. 57:131-146.

Zhang, N., Sun, Q., Li, H., Li, X., Cao, Y., Zhang, H., Li, S., Zhang, L., Qi, Y. and Ren, S. 2016. Melatonin improved anthocyanin accumulation by regulating gene expressions and resulted in high reactive oxygen species scavenging capacity in cabbage. - Font. Plant Sci. 7: 197. doi: 10.3389/fpls.2016.00197.

Zhang, N., Zhang, H.J., Zhao, B., Sun, Q.Q., Cao, Y.Y., Li, R., Wu, X.X., Weeda, S., Li, L. and Ren, S. 2014. The RNA-seq approach to discriminate gene expression profiles in response to melatonin on cucumber lateral root formation. - J. Pineal. Res. 56: 39-50.

Zhang, N., Zhao, B., Zhang, H.J., Weeda, S., Yang, C., Yang, Z.C., Ren, S. and Guo, Y.D. 2013. Melatonin promotes water-stress tolerance, lateral root 
formation, and seed germination in cucumber (Cucumis sativus L.). - J. Pineal. Res. 54: 15-23.

Zhao, Y., Tan, D.X., Lei, Q., Chen, H., Wang, L., Li, Q.t., Gao, Y. and Kong, J. 2013. Melatonin and its potential biological functions in the fruits of sweet cherry. - J. Pineal. Res. 55: 79-88.

\section{How to cite this article:}

Oloumi, H., Nasibi, H and Mozaffari, H. 2018. Investigation of the growth rate and secondary metabolites content of Lepidium sativum under exogenous melatonin treatment. - Nova Biologica Rep. 2018: 144-154.

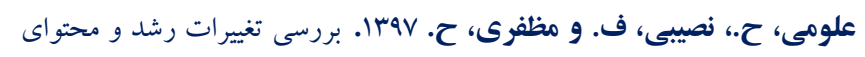

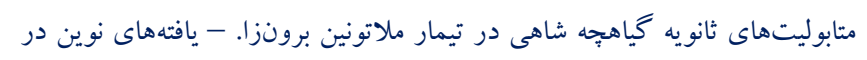

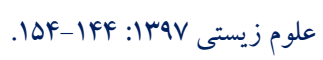

